\title{
Beyond the Patriot Act: Rulings from the Office of Foreign Asset Control (OFAC) and their Effects on Canadian Libraries
}

Andrew Waller

Serials Librarian

University of Calgary Library

2500 University Drive NW

Calgary, AB

T2N 1N4

waller@ucalgary.ca

(403) 220-8133 voice

(403) 284-2109 fax

Author Biography: Andrew Waller is Serials Librarian at the University of Calgary where he oversees the serials collection and does the licensing work for e-journals and other electronic resources. He writes and speaks on topics such as e-journals, Open Access, and licensing.

Abstract: OFAC is the Office of Foreign Assets Control, part of the United States Department of the Treasury. OFAC governs sanctions against countries embargoed by the United States and has released rulings that have implications on the licenses signed by Canadian libraries and the provision of information to library users. This paper investigates the effects of the OFAC rulings and presents some suggestions for dealing with these in the Canadian library community.

Keywords: OFAC, licensing, electronic products, libraries, Canada

\section{Introduction}

Over the last few years, there has been much concern in the Canadian library community and in other sectors in Canada about the effects of the 
USA PATRIOT Act. Reports have been written and positions taken in response to this American legislation. In addition to the PATRIOT Act, however, there are other items that emanate from agencies of the United States federal government that can affect Canadian libraries. This brief paper looks at the rulings from one of these bodies, the Office of Foreign Assets Control (OFAC).

\section{What is OFAC?}

The Office of Foreign Assets Control (OFAC) is a unit of the United States Department of the Treasury (Office of Foreign Assets Control). It...

"administers and enforces economic sanctions programs primarily against countries and groups of individuals, such as terrorists and narcotics traffickers. The sanctions can be either comprehensive or selective, using the blocking of assets and trade restrictions to accomplish foreign policy and national security goals" (Frequently Asked Questions and Answers, OFAC).

In recent years, the OFAC has released rulings that are directed at countries under U.S. interdiction, such as Cuba, Iran, and Sudan, and which deal with what OFAC deems "informational materials". OFAC is most well-known in the university community for a series of regulations that initially prohibited and later permitted most peer review publishing that involves authors from embargoed nations. In terms of Canadian libraries, particularly academic libraries, OFAC rulings can have serious implications on licensing activities and, as a consequence, on the provision of information to library users.

\section{OFAC, Licenses, and the Provision of Information}

Most Canadian academic libraries (and most Canadian libraries in general) now have access to hundreds, if not thousands, of electronic journals and other electronic information products. In large part, these are not locally loaded and are accessed at a distance by users, mostly from servers in other countries, the United States chief among them ${ }^{1}$. Some of this electronic content is owned by the libraries, some is leased. All of these 
products are governed by licenses, negotiated between the publisher or seller, the "licensor", and the libraries or their agents (such as consortia or serial vendors), the "licensee".

Interpretation of OFAC regulations has caused some American-based journal publishers to insert clauses into their recent licenses that forbid a licensee, such as a library, from giving access to authorized users (in the case of a university, faculty, staff, and students) located in countries under American embargo (authorized users from proscribed countries who are physically at a Canadian academic institution or library are exempt from this prohibition). This can be seen clearly in two licenses. The license that came with the 2004 renewal for the American Medical Association (AMA) journals, which include the well-known Journal of the American Medical Association (JAMA), contains this line:

Licensee agrees that it shall not make the Licensed Materials available in such countries as advised in writing by AMA where such availability may be prohibited by U.S. law... (American Medical Association Academic Site License

The license for the SPIE Digital Library, a product from the Society of Photo-Optical Engineers (SPIE), includes more stringent wording:

SPIE shall not be required to distribute, and Licensee shall not redistribute, the Licensed Material or any article therein to a country to which export is prohibited by U.S. law or regulation (SPIE Digital Library Multi-Site License Agreement).

For libraries that sign licenses with these clauses, there are many potential problems. Canadian universities have established distance education programs and other cooperative ventures in countries that fall under U.S. embargo. Canadian researchers work with colleagues in these countries and teach and conduct research there. Accordingly, university libraries are obliged under their own rules of fairness, to supply information resources to authorized users in these nations. This is, of course, is in direct contradiction to the provisions of licenses such as those from AMA and SPIE. If a library decides to provide licensed information to authorized users in embargoed countries in the face of a license that supposedly prohibits this, there could be repercussions. While the library would be 
helping users and supporting freedom of information, if this action was discovered, the library could be judged to be in violation of a signed agreement and lose access to the content in question. The resulting uproar from users, who are generally very fond of electronic resources, particularly in the academic environment, would likely be difficult to deal with.

Some Canadian libraries have attempted to remove the contentious clauses from the AMA and SPIE licenses, so far unsuccessfully. Though publishers may recognize and sympathize with the difficulties Canadian libraries could experience under these licenses, the fear of action from American federal authorities is a stronger motivation for leaving the embargo wording in place.

It should be noted that clauses of the same nature as those in the AMA and SPIE licenses have not yet proliferated in licenses from other American-based publishers, but the "force majeure" sections of most licenses now include "government restrictions" or a similar term as something for which the licensor will not be responsible (along with natural disasters, war, and the like). It is impossible to remove a force majeure section from a license, so this catch-all wording will probably remain in licenses indefinitely.

Lastly, it is also worth noting that the OFAC regulations are interpretations of American legislation by that particular unit of the Treasury Department. Two pieces of legislation passed by Congress, the Berman Amendment (1989) and the Free Trade in Ideas Amendment (1994) ${ }^{2}$, state that "informational materials" are specifically excluded from any trade sanctions. The OFAC regulations constitute very narrow interpretations of these amendments 3 ; clearly, not all "informational materials" have been viewed as exempt by OFAC. Looking at the OFAC rulings in detail, it could even be argued that their regulations do not apply to the provision of information to embargoed countries, only the importation of information, in the form of manuscripts, from such nations.

\section{What Can Canadian Libraries Do?}

As libraries and others are finding with the USA PATRIOT Act, it is very 
difficult to influence the legislation and policies of another country; however, there are actions that can be taken at home to ameliorate the situation. The same is true when dealing with the effects of OFAC rulings, at least to a certain extent. Here are a few suggestions:

- Become aware of and keep informed on the issue. It can be said that this is an obvious thing but, in this day of information overload, this can be a difficult thing to do. Especially in terms of the OFAC rulings, however, it is important to be vigilant.

- Carry out good licensing practices. First, every electronic product license needs to be looked at with due diligence. Know which items are the most important to an institution, and keep an eye out for troublesome clauses. Hopefully, this will catch OFAC-influenced wording. It is also important to be willing to ask questions about and to negotiate licenses; this may not lead to the removal of, or changes to sections, but it indicates that the licensee is a serious and aware partner in the relationship with the licensor.

- Bring up the topic with publishers, particularly those based in the United States. Again, for those publishers that have licenses that contain embargo-related clauses, they may feel that they are not able to make changes to their licenses but they will hear the concerns of their customers. For those publishers that have OFACexempt licenses, they may become better informed on the matter.

- Talk with others in the Canadian library community. Not all library workers are aware of the effects of the OFAC pronouncements not everyone who is informed about this issue agrees that this matter is of concern - but spreading awareness can, at the very least, lead to discussion, if not action.

- Talk with users and decision-makers. At a university, for instance, this includes the members of the campus community, faculty, administration, staff, and students, all of whom are stakeholders in the university library and should be concerned about access to information.

\section{Conclusion}

It is clear that the rulings of the Office of Foreign Assets Control can potentially pose problems for Canadian libraries. Thankfully, in some ways, the worst of these difficulties have not yet come to fruition; for 
example, the author's library did, very reluctantly, sign the 2004 American Medical Association license and, so far, has received no instructions from the AMA to cease the provision of AMA journal content to students in Cuba, Sudan, or Iran. There is no guarantee that this will remain the same in the future. Even it does, however, as we have learned in recent years, it is wise for the Canadian library community to keep its collective finger on the pulse of the United States federal government and its departments.

\section{Notes}

1. Office of Foreign Assets Control, 31 August, $2006<$ http://www.treas.gov/ offices/enforcement/ofac/>.

\section{Frequently Asked Questions and Answers, Office of Foreign

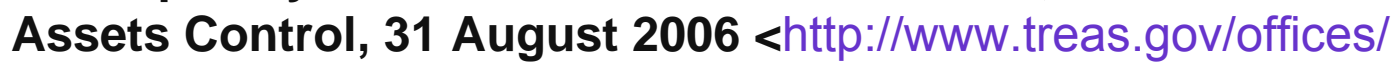 enforcement/ofac/faq/answer.shtml\#1>.}

3. Scholar's Portal is the main exception to this. The electronic content that the Ontario Council of University Libraries (OCUL) members' access is locally loaded.

4. American Medical Association Academic Site License, USCD Libraries Acquisitions Department, 31 August 2006 <http://orpheus-1.ucsd.edu/acq/ license/ama.pdf>.

5. SPIE Digital Library Multi-Site License Agreement, USCD Libraries Acquisitions Department, 31 August 2006 <http://orpheus-1.ucsd.edu/acq/ license/cdlspie.pdf>.

6. The Berman and Free Trade in Ideas amendments amend earlier pieces of legislation. These citations list the changes implemented by these amendments.

Trading with the Enemy Act, 50 U.S.C.A. App. s. 5(b)(4) (par.(4) added by Omnibus Trade and Competitiveness Act, Pub.L. No. 100-418, s. 2502, 102 Stat. 1107 (1988) and amended by the Foreign Relations Authorization Act, Fiscal Years 1994 and 1995, Pub. L. No. 103-236, s. 
525 (“Free Trade in Ideas"), 108 Stat. 382 (1994))

International Emergency Economic Powers Act, 50 U.S.C.A. s.1702 (b)(3) and (4) (par.(3) added by Omnibus Trade and Competitiveness Act, Pub.L. No. 100-418, s. 2502, 102 Stat. 1107 (1988) and new par.(3) added and par.(4) added by the Foreign Relations Authorization Act, Fiscal Years 1994 and 1995, Pub. L. No. 103-236, s. 525 ("Free Trade in Ideas"), 108 Stat. $382(1994))$

7. For a little more information on OFAC's interpretation of the Berman Amendment, see:

Peter Gilver, "The Defendant Is Charged with Good Editing," Journal of Scholarly Publishing 36.1 (2004): 1-5, 31 August 2006 <http://muse.jhu. edu/journals/journal_of_scholarly_publishing/v036/36.1gilver. html>.

\section{Footnotes}

1Scholar's Portal is the main exception to this. The electronic content that the Ontario Council of University Libraries (OCUL) members' access is locally loaded.

2The Berman and Free Trade in Ideas amendments amend earlier pieces of legislation. These citations list the changes implemented by these amendments.

Trading with the Enemy Act, 50 U.S.C.A. App. s. 5(b)(4) (par.(4) added by Omnibus Trade and Competitiveness Act, Pub.L. No. 100-418, s. 2502, 102 Stat. 1107 (1988) and amended by the Foreign Relations Authorization Act, Fiscal Years 1994 and 1995, Pub. L. No. 103-236, s. 525 ("Free Trade in Ideas"), 108 Stat. 382 (1994))

International Emergency Economic Powers Act, 50 U.S.C.A. s.1702 (b) (3) and (4) (par.(3) added by Omnibus Trade and Competitiveness Act, Pub.L. No. 100-418, s. 2502, 102 Stat. 1107 (1988) and new par.(3) added and par.(4) added by the Foreign Relations Authorization Act, Fiscal Years 1994 and 1995, Pub. L. No. 103-236, s. 525 ("Free Trade in Ideas"), 108 Stat. 382 (1994)) 
3For a little more information on OFAC's interpretation of the Berman Amendment, see:

Gilver, Peter. "The Defendant Is Charged with Good Editing," Journal of Scholarly Publishing 36.1 (2004): 1-5. 31 August 2006 <http://muse. jhu.edu/journals/journal_of_scholarly_publishing/v036/36.1gilver. html>.

\section{Works Cited}

American Medical Association Academic Site License, USCD Libraries Acquisitions Department, 31 August 2006 <http://orpheus-1.ucsd.edu/ acq/license/ama.pdf>.

Frequently Asked Questions and Answers. Office of Foreign Assets Control. 31 August 2006 <http://www.treas.gov/offices/enforcement/ ofac/faq/answer.shtml\#1>.

Gilver, Peter. "The Defendant Is Charged with Good Editing," Journal of Scholarly Publishing 36.1 (2004): 1-5. 31 August 2006 <http://muse. jhu.edu/journals/journal_of_scholarly_publishing/v036/36.1gilver. html>.

International Emergency Economic Powers Act, 50 U.S.C.A. s.1702 (b) (3) and (4) (par.(3) added by Omnibus Trade and Competitiveness Act, Pub.L. No. 100-418, s. 2502, 102 Stat. 1107 (1988) and new par.(3) added and par.(4) added by the Foreign Relations Authorization Act, Fiscal Years 1994 and 1995, Pub. L. No. 103-236, s. 525 ("Free Trade in Ideas"), 108 Stat. 382 (1994))

Office of Foreign Assets Control, United States Department of the Treasury. 31 August, $2006<$ http://www.treas.gov/offices/enforcement/ ofac/>.

SPIE Digital Library Multi-Site License Agreement, USCD Libraries Acquisitions Department, 31 August 2006 <http://orpheus-.ucsd.edu/ acq/license/cdlspie.pdf>.

Trading with the Enemy Act, 50 U.S.C.A. App. s. 5(b)(4) (par.(4) added by Omnibus Trade and Competitiveness Act, Pub.L. No. 100-418, s. 2502, 102 Stat. 1107 (1988) and amended by the Foreign Relations Authorization Act, Fiscal Years 1994 and 1995, Pub. L. No. 103-236, s. 525 ("Free Trade in Ideas"), 108 Stat. 382 (1994)) 